\title{
Technical note: A modified method to quantify prolamin proteins in dry and high-moisture corn
}

\author{
S. E. Nellis, P. C. Hoffman, ${ }^{1}$ and R. D. Shaver \\ Department of Dairy Science, University of Wisconsin, Madison 53706
}

\section{ABSTRACT}

Numerous studies have evaluated laboratory methods to quantify prolamin proteins in dry corn; however, the utility of methods to quantify functional prolamins, which impede starch digestibility, in high-moisture corn (HMC) is less defined. As a result, a common rapid turbidimetric (rTM) laboratory procedure was modified (rapid Bradford method, rBM), extracting buffer-soluble proteins before prolamin solubilization in an effort to better quantify functional prolamins in HMC. Twenty samples of dry and HMC were evaluated by rTM and rBM procedures. Prolamin concentration in dry corn, as estimated by rTM or rBM methods, ranged from 6.12 to $2.20 \mathrm{~g} / 100 \mathrm{~g}$ of $\mathrm{DM}$ or 5.46 to 2.41 $\mathrm{g} / 100 \mathrm{~g}$ of DM, respectively. Dry corn mean prolamin concentrations, as estimated by rTM or rBM methods, were similar at 3.65 or $3.66 \mathrm{~g} / 100 \mathrm{~g}$ of DM. Prolamin concentration in HMC, as estimated by rTM, ranged from 4.99 to $3.24 \mathrm{~g} / 100 \mathrm{~g}$ of DM, with a mean prolamin concentration of $4.19 \mathrm{~g} / 100 \mathrm{~g}$ of $\mathrm{DM}$, but estimation of prolamins in HMC by the rBM method resulted in lower mean (4.19 vs. $3.24 \mathrm{~g} / 100 \mathrm{~g}$ of $\mathrm{DM})$ prolamin concentration. Prolamin concentration in dry and HMC measured by rTM was negatively related to peak absolute rates (PAR; $\mathrm{mL} / 0.1 \mathrm{~g}$ of $\mathrm{DM}$ ) of in vitro gas production. However, relationships between rTM prolamin concentration and PAR were not homogeneous and were different between dry and HMC. Prolamin proteins as determined by rBM were likewise negatively related to PAR, but corn type did not influence rBM prolamin concentration by PAR relationships. Data suggest that the rBM method defined more similar functional prolamin proteins, which impede starch degradability, in dry and HMC.

Key words: prolamin, high-moisture corn, starch degradability

Received January 14, 2013.

Accepted April 9, 2013.

${ }^{1}$ Corresponding author: pchoffma@wisc.edu

\section{Technical Note}

Corns with greater percentages of prolamin proteins have been shown to reduce starch degradability or digestibility, both in vitro (Hoffman et al., 2012) and in vivo (Lopes et al., 2009). Recently, Larson and Hoffman (2008) defined a low-cost, rapid turbidity method (rTM) to quantify prolamin proteins (zein) in dry corns of varying endosperm type. Since publication, the utility of the rTM has been evaluated in numerous studies. Giuberti et al. (2011) found the rTM to yield similar prolamin values for dried corn compared with the intensive methods of Landry et al. (2000) but yielded lower prolamin values compared with the method of Hamaker et al. (1995). Based on the work of Landry et al. (2002), Giuberti et al. (2012) modified the rTM, replacing isopropanol with tert-butanol to extract greater percentages of prolamins from dry and high-moisture corn (HMC).

The utility of the rTM in ruminant nutrition has also been evaluated in numerous studies. Lopes et al. (2009) quantified prolamin proteins using the rTM in near-isogenic variants of an Oh43x W64A normal dent endosperm hybrid carrying floury-2 or opaque-2 alleles. Hybrids carrying floury-2 or opaque-2 alleles contained significantly less prolamin protein, resulting in improved in vivo starch digestibility in lactating dairy cows. Hoffman et al. (2012) and Masoero et al. (2011) demonstrated negative relationships between rTM prolamin contents of dry corn and in vitro starch degradability.

The biological utility of the rTM in evaluating prolamins in HMC or corn silage is less defined because relationships between rTM prolamins in HMC or corn silage and starch degradability are not well established. Using HPLC methods, Hoffman et al. (2011) demonstrated that fermentation of HMC reduced all $\alpha, \beta$, $\gamma$, and $\delta$ prolamin-zein subunits of the starch-protein matrix from 10 to $40 \%$, but rTM did not detect changes in prolamin concentration induced by fermentation. Likewise, Hoffman et al. (2012) could not illicit relationships between prolamin protein in HMC and peak absolute rate (PAR) of in vitro gas production when prolamin was determined by rTM. These data suggest 
that the rTM as defined by Larson and Hoffman, (2008) may improperly define the biological functionality of prolamin proteins, as related to starch digestibility, in HMC. It was the objective of the current study to explore whether the rTM could be modified to quantify prolamin proteins in HMC, which are biologically more relevant to starch degradability in ruminants.

The rTM of Larson and Hoffman, (2008) can be generalized as follows: dried ground corn is defatted using acetone (100\%), filtered, and dried, and acetone-insoluble DM is retained. Prolamins in acetone-insoluble DM are solubilized with $55.0 \%$ aqueous isopropyl alcohol containing $0.6 \% 2$-mercaptoethanol. Turbidity of prolamin protein is achieved by incorporation of aqueous alcohol-solubilized prolamins with $0.15 \mathrm{M}$ TCA. The degree of turbidity is measured by the logarithm of absorbance of the sample at $440 \mathrm{~nm}$ on a spectrophotometer and prolamin concentration is quantified using a standard absorbance curve developed from purified zein.

Intuitive shortcomings of the rTM exist with regard to measuring prolamins in HMC. First, the acetone rinse is designed to remove fat, with minimal loss of total proteins in the sample, because only prolamin proteins are assumed to become turbid in $0.15 \mathrm{M}$ TCA (Larson and Hoffman, 2008). This assumption may be invalid for HMC, as proteolytic activity during fermentation may hydrolyze prolamin proteins into dysfunctional peptides, which may express turbidity in $0.15 \mathrm{M}$ TCA. Second, turbidity in chloroacetic acid is rapid but not purely quantitative because turbidity is affected differently by differences in the tertiary structure of proteins (Ebina and Nagai, 1979).

Due to potential shortcomings and new information regarding efficiency of tert-butanol to extract prolamins (Giuberti et al., 2012), the following modifications were made to the rTM in an effort to improve its biological utility in determining functional prolamins, as related to starch digestibility, in HMC: (1) to facilitate removal of nonfunctional endosperm proteins (albumins, globulins, and hydrolyzed zein) in corn, defatting the sample with acetone in the rTM was replaced with a borate phosphate buffer extraction to remove buffer-soluble proteins as defined by Krishnamoorthy et al. (1983); (2) use of isopropanol to extract prolamins was abandoned and replaced with tert-butanol to more efficiently extract prolamins (Giuberti et al., 2012); and (3) because extraction of prolamins with tert-butanol without prior defatting of the sample with acetone would influence turbidity measurements, turbidity in $0.15 \mathrm{M}$ TCA was abandoned and replaced with a Bradford protein assay (Bradford, 1976) to quantify prolamin proteins solubilized in tert-butanol. The changes were coalesced and defined as a rapid Bradford method (rBM) to quantify prolamin proteins in dry and HMC.

Buffer-soluble proteins in dried ground corn are extracted using a borate phosphate buffer as defined by Krishnamoorthy et. al. (1983), and buffer-insoluble DM (biDM) is retained. Prolamins in biDM are solubilized with $60.0 \%$ aqueous tert-butyl alcohol containing $0.6 \%$ 2-mercaptoethanol. Prolamin proteins are quantified using Coomassie Brilliant Blue dye (BP100-25 Brilliant Blue G-250; Fisher Scientific, Fair Lawn, NJ) in an acidic media, with the reddish dye turning blue when it binds to protein (Bradford, 1976). The colorimetric shift is measured on a spectrophotometer at a $595-\mathrm{nm}$ wavelength and compared with a prolamin standard. The apparatus include a spectrophotometer set to 595 $\mathrm{nm}$, forced-air ovens set to 55 and $105^{\circ} \mathrm{C}$, balance accurate to $1 \mathrm{mg}$, centrifuge capable of $2,250 \times g$; vortex mixer, a cyclone mill fitted with a 1-mm screen, orbital shaker capable of $240 \mathrm{rpm}$, funnels capable of holding 125-mm Whatman 541 filter paper, 40-mL centrifuge tubes, 5-mL plastic disposable cuvettes, pipettes capable of dispensing $50 \mu \mathrm{L}$ or 1 to $10 \mathrm{~mL}$, and glassware including test tubes, 100 - and 1,000-mL volumetric flasks, and 125-mL Erlenmeyer flasks with stoppers.

Reagents included borate phosphate buffer $[12.2 \mathrm{~g}$ of sodium phosphate $\left(\mathrm{NaH}_{2} \mathrm{PO}_{4} \cdot \mathrm{H}_{2} \mathrm{O}\right)$ and $8.91 \mathrm{~g}$ of sodium borate $\left(\mathrm{Na}_{2} \mathrm{~B}_{4} \mathrm{O}_{7} \cdot 10 \mathrm{H}_{2} \mathrm{O}\right)$ per liter of distilled water $\left(\mathbf{d H}_{\mathbf{2}} \mathbf{O}\right)$, stirred at medium speed until completely dissolved]; aqueous alcohol solution $[600 \mathrm{~mL}$ of tert-butanol (CAS 75-65-0 Fisher Scientific), $6 \mathrm{~mL}$ of 2-mercaptoethanol (Fisher Scientific O34461-100), brought to volume in a $1,000-\mathrm{mL}$ volumetric flask with $\mathrm{dH}_{2} \mathrm{O}$ ]; Bradford reagent [100 mg of Coomassie Brilliant Blue powder dissolved in $5 \mathrm{~mL}$ of reagent alcohol (Fisher scientific A962P-4) and $100 \mathrm{~mL}$ of $85 \%$ (wt/ vol) phosphoric acid (Fisher Scientific UN1805) and brought to volume in a $1,000-\mathrm{mL}$ volumetric flask with $\left.\mathrm{dH}_{2} \mathrm{O}\right]$; and finally, a prolamin standard prepared in a 100-mL volumetric flask: $94 \mathrm{mg}$ of purified zein (CAS 9010-66-6; Acros Organics, Fair Lawn, NJ), $6 \mathrm{mg}$ of albumin standard (23209; Thermo Scientific, Waltham, MA), brought to volume with aqueous alcohol solution and stirred for $1 \mathrm{~h}$. The 94:6-mg ratio of purified zein to albumin was used as the standard to increase the absorbance per unit of $\mathrm{CP}(\mathrm{N})$ upon Bradford reagent addition because a prestudy evaluation (data not shown) of absorbance at $595 \mathrm{~nm}$ per unit of true $\mathrm{N}$ concentration (Lachat Instruments, 1995) in tertbutanol, 2- mercaptoethanol extracts of unknown corns was greater per unit of $\mathrm{N}$ compared with absorbance per unit of $\mathrm{N}$ of a pure zein standard.

Corn samples were dried in a $55^{\circ} \mathrm{C}$ forced-air oven for 24 to $48 \mathrm{~h}$. Samples were ground in a cyclone mill 
(Udy Corp., Boulder, CO) fitted with a 1-mm screen. The DM of the samples was determined by drying at $105^{\circ} \mathrm{C}$ for $3 \mathrm{~h}$.

Filter papers (Whatman 541) were placed in a $105^{\circ} \mathrm{C}$ oven for $2 \mathrm{~h}$, hot weights were recorded, and filters were folded to fit funnels. A 500-mg sample of dried, ground corn was placed into a $125-\mathrm{mL}$ Erlenmeyer flask, 50 $\mathrm{mL}$ of borate-phosphate buffer was added, and the flask was covered and incubated in a $39^{\circ} \mathrm{C}$ water bath for $1 \mathrm{~h}$. The contents were filtered through the funnel previously fitted with filter paper and the flask was rinsed with buffer to remove any remaining sample. The residue was then rinsed with an additional $150 \mathrm{~mL}$ of buffer. The filtrate was discarded and the biDM and filter paper were left to air dry for $1 \mathrm{~h}$ and then dried in a $55^{\circ} \mathrm{C}$ forced-air oven for $24 \mathrm{~h}$. The dry weight of the biDM and filter paper was then recorded.

A 200-mg subsample of biDM was weighed into 40$\mathrm{mL}$ centrifuge tubes, $20 \mathrm{~mL}$ of the aqueous alcohol solution was added, and the tube was covered and shaken on an orbital shaker at $240 \mathrm{rpm}$ for $4 \mathrm{~h}$. Tubes were then centrifuged at 2,250 $\times g$ for $20 \mathrm{~min}$. The Bradford solution was readied by inverting the container 2 to 3 times to mix, and then the solution was filtered through 541 Whatman filter paper fitted in a funnel placed over a $125-\mathrm{mL}$ Erlenmeyer flask and was brought to room temperature.

Prolamin standards were prepared containing 0, $212.5,425,637.5$, and $850 \mu \mathrm{g} / \mathrm{mL}$. In 5 test tubes, $0 \mathrm{~mL}$ of prolamin standard solution was added to the first tube, and then 1, 2, 3, and $4 \mathrm{~mL}$, respectively. Next, 4 $\mathrm{mL}$ of aqueous alcohol solution was added to the first tube, and then $3,2,1$, and $0 \mathrm{~mL}$, respectively. Each tube was vortexed gently for 2 to $3 \mathrm{~s}, 50 \mu \mathrm{L}$ of each standard solution was pipetted into cuvettes, $2.5 \mathrm{~mL}$ of Bradford reagent was added, and then samples were incubated at room temperature for $5 \mathrm{~min}$. After a blank standard $(0 \mu \mathrm{g}$ of prolamin $/ \mathrm{mL})$ was used to set the spectrophotometer $(595 \mathrm{~nm})$ to zero, the absorbance of each standard was read and a standard curve was fit using the known prolamin concentrations $(\mu \mathrm{g} / \mathrm{mL})$ as the dependent variable and the absorbance as the independent variable.

After centrifuging, $50 \mu \mathrm{L}$ of supernatant from each unknown sample was pipetted into cuvettes, $2.5 \mathrm{~mL}$ of Bradford reagent was added, and samples were incubated at room temperature for $5 \mathrm{~min}$. Then, the absorbance of each sample was measured at $595 \mathrm{~nm}$.

Calculations were as follows:

Buffer-insoluble DM recovery (biDMr), g/100 g of DM $=[($ filter paper + biDM residue, $\mathrm{g} \times 0.994)$

- (filter paper weight, g)]/(sample weight, g of DM);
Prolamin concentration, $\mathrm{g} / 100 \mathrm{~g}$ of $\mathrm{DM}=$

$[($ prolamin, $\mu \mathrm{g} / \mathrm{mL} \times 0.02) /(\mathrm{biDM}$ sample weight, $\mathrm{mg} \times \mathrm{biDMr})] \times 100$.

To evaluate repeatability and utility of the proposed rBM, 20 samples of dry corn with varying $\mathrm{CP}$ content and 20 samples of HMC with varying DM content were procured from the University of Wisconsin Soil and Forage Testing Laboratory (Marshfield, WI). Dry corn samples (whole kernel), previously dried at $55^{\circ} \mathrm{C}$ for 24 $\mathrm{h}$, and HMC after drying for $24 \mathrm{~h}$ at $55^{\circ} \mathrm{C}$ were divided into 2 subsamples, with one subsample ground through a cyclone mill fitted with a 1-mm screen and analyzed for DM, CP (AOAC, 1990), and soluble CP (SOLCP; Krishnamoorthy et al., 1983). The starch content of samples was estimated using near-infrared reflectance spectroscopy (Soil and Forage Analysis Laboratory). Prolamin contents of dry and HMC corns were then determined by rTM (Larson and Hoffman, 2008) and rBM methods as defined above. Prolamin concentration was determined in duplicate in 2 separate runs to provide inference of method precision. Estimates of rTM and rBM precision were calculated by the methods defined by Bland and Altman, (2010). The repeatability standard deviation $\left(\mathbf{S}_{\mathbf{r}}\right)$ was estimated as the mean of the absolute differences between duplicates for each method (Bland and Altman, 2010) and $S_{r}$ was alternatively expressed as relative $\mathrm{S}_{\mathrm{r}}\left[\mathbf{R} \mathrm{S}_{\mathrm{r}}=\left(\mathrm{S}_{\mathrm{r}} /\right.\right.$ mean value) $\times 100$ ], expressing repeatability as a percentage of the mean.

To evaluate the biological utility of rTM or rBM for prolamin, the remaining subsamples of dry and HMC were ground through a cutter mill (Arthur H. Thomas Co., Philadelphia, PA) fitted with a 2-mm screen and saved for in vitro gas production determinations. Detailed in vitro gas production methods have been previously published in Hoffman et al. (2012). General conditions of in vitro gas production determinations were as follows: in vitro gas production was measured on 2-mm ground dry and HMC samples using the Ankom-RFS system (Ankom Technology Corp., Macedon, NY) fitted with wireless transponders (Leibovich et al., 2009) using the in vitro technique of Goering and Van Soest (1970). In vitro gas production was measured in triplicate utilizing 3 separate in vitro runs with all samples of dry or HMC included in each run. In vitro gas production was determined on 0.5 -g samples incubated for $24 \mathrm{~h}$ in a water bath maintained at $39^{\circ} \mathrm{C}$. Rumen fluid was obtained from 2 lactating dairy cows fitted with ruminal cannula, fed a diet containing approximately $30 \%$ alfalfa-grass silage, $40 \%$ corn silage, and $25 \%$ ground dry shelled corn, with the remainder of the diet containing protein, vitamin, and mineral 
Table 1. Nutrient composition of dry and high-moisture corns used in the evaluation of the rapid turbidity or rapid Bradford method to determine prolamin content

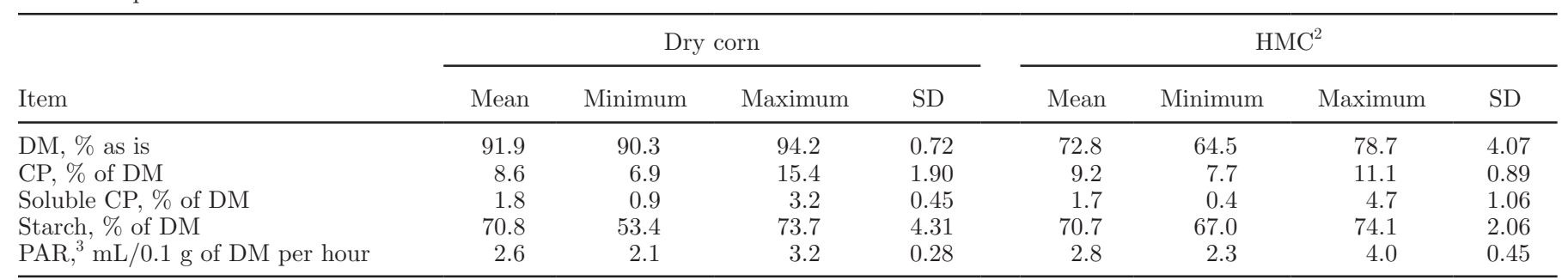

${ }^{1}$ All values are expressed as a percentage of DM, unless otherwise specified.

${ }^{2}$ High-moisture corn.

${ }^{3}$ Peak absolute rate of in vitro gas production.

supplements. After collection, rumen fluid was held at $39^{\circ} \mathrm{C}$ in $\mathrm{CO}_{2}$-gassed vessels, mixed in a $\mathrm{CO}_{2}$-gassed blender, and strained through 3 layers of cheesecloth before injection into the gas incubation flask. A blank (rumen fluid only) was included within each in vitro gas production run.

Cumulative in vitro gas production pressure of all samples was recorded every $0.25 \mathrm{~h}$, with adjustment for the gas production of a blank sample within run. Gas production pressure readings were converted to gas volume and expressed as milliliters per $0.1 \mathrm{~g}$ of DM, resulting in expression of gas production volumes between 0 and $50 \mathrm{~mL}$ (Parissi et al., 2005). The PAR of gas production $(\mathrm{mL} / 0.1 \mathrm{~g}$ of $\mathrm{DM}$ per hour), defined as the peak of the first derivative (Lanzas et al., 2007) of the smoothed cumulative gas production curves, was selected to represent ruminal degradation potential of dry and HMC as defined by Hoffman et al. (2012). Because all dry or HMC samples were represented in each run, the run average PAR for all corns was used as an internal standard. For dry and HMC, differences between the 3-run average PAR of the internal standard and the individual run average PAR were added to each test sample observation to minimize betweenrun variation.

Differences between mean prolamin concentrations, $\mathrm{S}_{\mathrm{r}}$, and $\mathrm{RS}_{\mathrm{r}}$ of the rTM and rBM were conducted using the PROC ANOVA procedures of SAS (SAS Institute, 2001), with assay method, corn type, and their interaction in the model. For $\mathrm{S}_{\mathrm{r}}$ and $\mathrm{RS}_{\mathrm{r}}$, the absolute or relative (\% of mean) absolute differences between duplicates of the same corn were used as population variables for statistical analysis. Relationship differences between in vitro gas production (PAR) by corn type and prolamin concentrations as determined by the rTM were evaluated using the heterogeneity of slopes test (Littell et al., 1993). Because relationships between rBM prolamin concentrations were second order, heterogeneity of slopes tests were conducted on natural logarithmic transformations of PAR values.
Nutrient compositions of dry and HMC used in the evaluation of the rTM and rBM are presented in Table 1. For dry corns, DM, CP, SOLCP, and starch concentrations had ranges of $3.9,8.5,2.3$, and 20.3 percentage units, respectively. Similar nutrient composition variance was observed within selected HMC, with DM, $\mathrm{CP}$, SOLCP, and starch concentrations with ranges of $14.2,3.4,4.3$, and 7.1 percentage units, respectively. Likewise, PAR had ranges of 1.1 and $1.7 \mathrm{~mL} / 0.1 \mathrm{~g}$ of DM per hour for dry and HMC, respectively, indicating wide ranges of starch degradability potential (Hoffman et al., 2012).

Prolamin concentrations of dry and HMC, as determined by the rTM and rBM, are presented in Table 2. Prolamin concentrations were not different between corn types $(P=0.71)$ but were influenced by assay method $(P<0.01)$ and a corn type by assay interaction $(P<0.01)$ was observed. Because a corn type by assay interaction was observed $(P<0.01)$, summary statistics are presented independently for dry and HMC. Dry corn prolamin as estimated by the rTM ranged from 6.12 to $2.20 \mathrm{~g} / 100 \mathrm{~g}$ of $\mathrm{DM}$, with a mean prolamin content of $3.65 \mathrm{~g} / 100 \mathrm{~g}$ of DM. The mean dry corn prolamin concentration as estimated by the rBM was almost identical at $3.66 \mathrm{~g} / 100 \mathrm{~g}$ of DM. The dry corn $\mathrm{S}_{\mathrm{r}}$ for the rTM prolamin determination was $0.38 \mathrm{~g} / 100 \mathrm{~g}$ of DM and the $\mathrm{RS}_{\mathrm{r}}$ was $11.5 \%$ of the mean. The $\mathrm{S}_{\mathrm{r}}$ and $\mathrm{RS}_{\mathrm{r}}$ indexes of method precision (Bland and Altman, 2010) are almost identical to the $S_{r}$ and $R_{\mathrm{r}}$ values of the rTM as originally published by Larson and Hoffman (2008). Corn type did not influence $(P=0.12) \mathrm{S}_{\mathrm{r}}$ or $\mathrm{RS}_{\mathrm{r}}$ but $\mathrm{S}_{\mathrm{r}}$ and $\mathrm{RS}_{\mathrm{r}}$ were influenced by assay method $(P<0.03)$ and a corn type by assay interaction $(P=$ $0.03)$ was observed for $\mathrm{S}_{\mathrm{r}}$ but not for $\mathrm{RS}_{\mathrm{r}}(P=0.23)$.

Statistical differences between the rTM or rBM determination of mean prolamin concentration were primarily related to differences in determining prolamin concentrations in HMC. Mean prolamin concentration in HMC, as estimated by the rTM, was $4.19 \mathrm{~g} / 100$ $\mathrm{g}$ of DM compared with $3.24 \mathrm{~g} / 100 \mathrm{~g}$ of $\mathrm{DM}$ when 
Table 2. Statistical evaluation of the rapid turbidity or rapid Bradford method to determine prolamin content of dry and high-moisture corn ${ }^{1,2}$

\begin{tabular}{|c|c|c|c|c|c|c|c|c|}
\hline \multirow[b]{2}{*}{ Item $^{3}$} & \multicolumn{2}{|c|}{ Dry corn } & \multicolumn{2}{|c|}{ HMC } & \multirow[b]{2}{*}{$\mathrm{SE}$} & \multicolumn{3}{|c|}{$P$-value } \\
\hline & rTM & $\mathrm{rBM}$ & rTM & $\mathrm{rBM}$ & & Corn & Assay & $\begin{array}{c}\text { Corn } \\
\times \text { assay }\end{array}$ \\
\hline Mean & 3.65 & 3.66 & 4.19 & 3.24 & 0.170 & 0.71 & 0.01 & 0.01 \\
\hline $\mathrm{S}_{\mathrm{r}}$ & 0.38 & 0.71 & 0.42 & 0.43 & 0.076 & 0.12 & 0.03 & 0.03 \\
\hline $\mathrm{RS}_{\mathrm{r}}, \%$ & 11.5 & 19.4 & 10.7 & 13.3 & 2.17 & 0.12 & 0.02 & 0.23 \\
\hline Minimum & 2.20 & 2.41 & 3.10 & 1.92 & - & - & - & - \\
\hline Maximum & 6.12 & 5.62 & 4.99 & 4.53 & - & - & - & - \\
\hline SD & 0.94 & 0.84 & 0.50 & 0.69 & - & - & - & - \\
\hline
\end{tabular}

determined by the rBM. In contrast, the precision $\left(\mathrm{S}_{\mathrm{r}}\right.$ or $\mathrm{RS}_{\mathrm{r}}$ ) of determining prolamin concentration by the rTM or rBM was primarily related to decreases in precision when measuring prolamin concentrations in dry corn by the rBM.

The biological implications of measuring prolamin proteins in dry or HMC using the rTM is represented in the relationship between in vitro gas production PAR and rTM prolamin concentration (Figure 1). The heterogeneity of slope test (Littell et al., 1993) revealed that corn type $(P=0.01)$ and rTM prolamin concentration $(P<0.001)$ influenced in vitro gas production PAR, with a corn type by prolamin concentration interaction $(P=0.05)$ observed. The prolamin concentration by corn type interaction suggests that measurement of prolamin proteins in dry and HMC using the rTM resulted in independent biological relationships between PAR and prolamin concentration. At greater rTM prolamin concentrations $(>5.0 \mathrm{~g} / 100 \mathrm{~g}$ of DM), dry and HMC had similar in vitro degradability as indexed by PAR. However, at lesser rTM prolamin concentrations $(<3.5$ $\mathrm{g} / 100 \mathrm{~g}$ of DM), PAR indexes of in vitro degradability of HMC were greater than dry corns.

Modification of the rTM to the rBM appeared to mitigate the independent relationships between PAR and prolamin concentration in dry and HMC (Figure 2 ). Similar to rTM-determined prolamins, the rBM prolamin concentration $(P<0.001)$ negatively influenced in vitro gas production PAR, but the heterogeneity of slopes test (Littell et al., 1993) revealed that corn type $(P=0.24)$ had no influence on PAR and no rBM prolamin concentration by corn type interaction $(P=0.38)$ was observed. These data indicate that the rBM defined biologically similar prolamin proteins in dry and $\mathrm{HMC}$, which were negatively related to in vitro degradability as indexed by PAR.

In conclusion, the rTM of Larson and Hoffman, (2008) was found to be feasible in quantifying prolamin proteins (zein) in dry corns and data from this inves- tigation confirm that prolamin proteins are negatively related to in vitro degradation. However, this investigation suggest that the rTM of Larson and Hoffman, (2008) may over estimate functional prolamins that impede starch degradability in fermented feeds such as HMC. Removal of borate phosphate-soluble proteins before solubilization of prolamin proteins by aqueous tert-butanol appeared to largely resolve inconsistencies in biological relationships between prolamin protein and in vitro DM degradation potentials of dry and HMC. Finally, quantification of solubilized prolamin proteins using Coomassie brilliant blue powder (Bradford, 1976) was labor efficient and is a well-recognized alternative to turbidity to rapidly and economically quantify complex proteins.

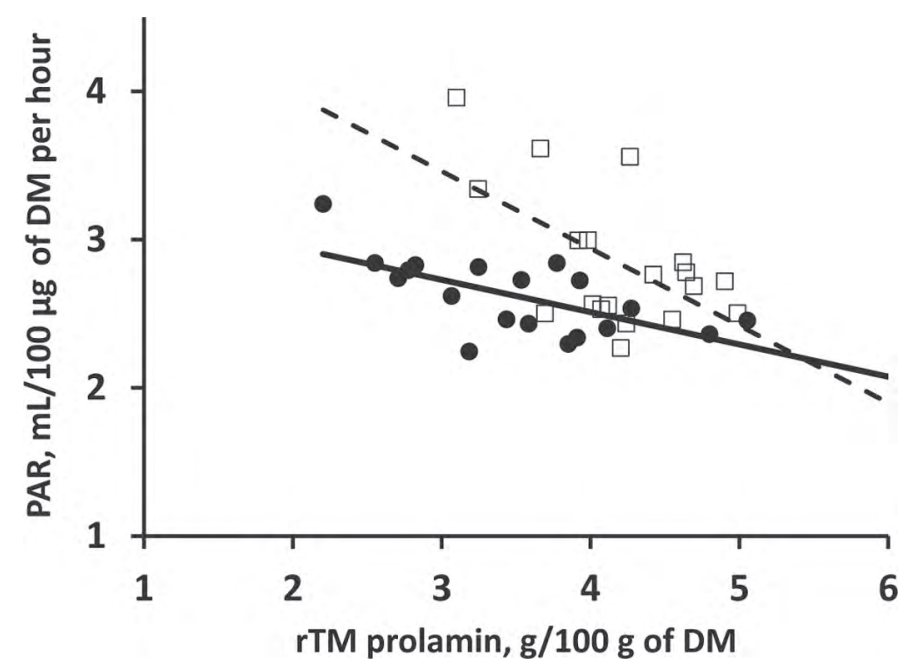

Figure 1. Relationships between peak absolute rate (PAR) of gas production and prolamin as determined by the rapid turbidity method (rTM) for dry corn $\left(--; \mathrm{R}^{2}=0.54, \mathrm{SE}=0.194\right)$ and high-moisture corn $\left(-\square-; \mathrm{R}^{2}=0.34, \mathrm{SE}=0.374\right)$. 


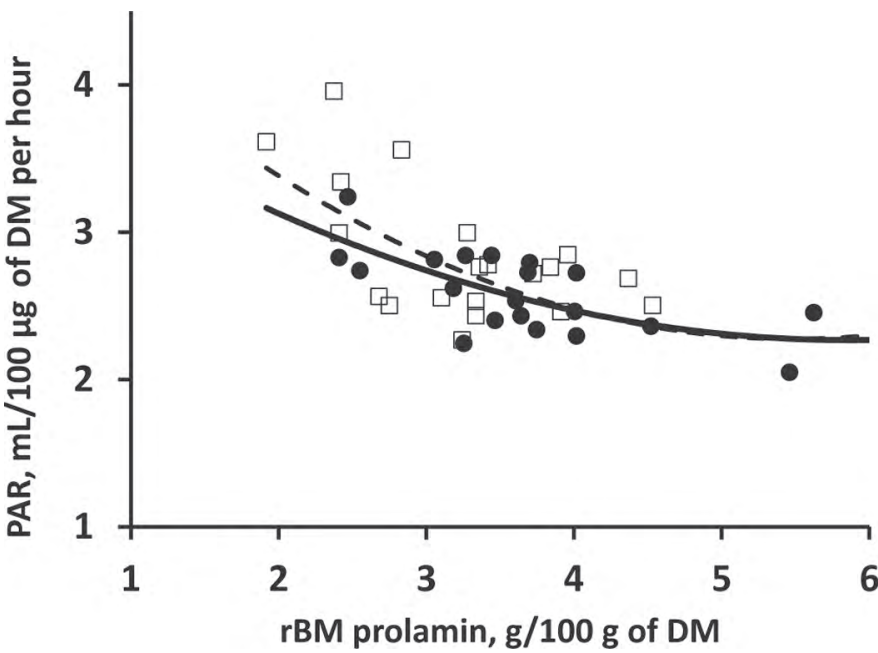

Figure 2. Relationships between peak absolute rate (PAR) of gas production and prolamin as determined by the rapid Bradford method $(\mathrm{rBM})$ for dry corn $\left(-\bullet ; \mathrm{R}^{2}=0.47, \mathrm{SE}=0.239\right)$ and high-moisture corn $\left(-\square-; \mathrm{R}^{2}=0.48, \mathrm{SE}=0.342\right)$.

\section{ACKNOWLEDGMENTS}

The authors thank Magdalena Kurtz and James Bailey of Bailey Consulting (DeForest, WI) for their financial contributions and support of unrestricted academic research.

\section{REFERENCES}

AOAC (Association of Official Analytical Chemists). 1990. Official Methods of Analysis. 15th ed. AOAC, Arlington, VA.

Bland, J. M., and D. G. Altman. 2010. Statistical methods for assessing agreement between two methods of clinical measurement. Int. J. Nurs. Stud. 47:931-936.

Bradford, M. M. 1976. A rapid and sensitive method for the quantitation of microgram quantities of protein utilizing the principle of protein-dye binding. Anal. Biochem. 72:248-254.

Ebina, S., and Y. Nagai. 1979. Re-evaluation of turbidimetry of proteins by use of aromatic sulfonic acids and chloroacetic acids. Clin. Chem. 25:247-251.

Giuberti, G., A. Gallo, and F. Masoero. 2011. A comparison of methods to quantify prolamin protein contents in cereals. Ital. J. Anim. Sci. 10:7-13.

Giuberti, G., A. Gallo, and F. Masoero. 2012. Quantification of zeins from corn, high-moisture corn, and corn silage using a turbidimet- ric method: Comparative efficiencies of isopropyl and tert-butyl alcohols. J. Dairy Sci. 95:3384-3389.

Goering, H. K., and P. J. Van Soest. 1970. Pages 8-11 in Forage Fiber Analyses (Apparatus, Reagents, Procedures, and Some Applications). Agric. Handbook No. 379. US Department of AgricultureAgricultural Research Service (USDA-ARS), Washington, DC.

Hamaker, B. R., A. A. Mohamed, J. E. Habben, C. P. Huang, and B. A. Larkins. 1995. Efficient procedure for extracting maize and sorghum kernel proteins reveals higher prolamin contents than the conventional method. Cereal Chem. 72:583-588.

Hoffman, P. C., N. M. Esser, R. D. Shaver, W. Coblentz, M. P. Scott, A. L. Bodnar, R. Schmidt, and B. Charley. 2011. Influence of inoculation and storage time on alteration of the starch-protein matrix in high moisture corn. J. Dairy Sci. 94:2465-2474.

Hoffman, P. C., D. R. Mertens, J. Larson, W. K. Coblentz, and R. D Shaver. 2012. A query for effective mean particle size of dry and high moisture corns. J. Dairy Sci. 95:3467-3477.

Krishnamoorthy, U., C. J. Sniffen, M. D. Stern, and P. J. Van Soest. 1983. Evaluation of a rumen mathematical model and in vitro simulated proteolysis to estimate the undegraded dietary nitrogen content of the feedstuff. Br. J. Nutr. 50:555-568.

Lachat Instruments. 1995. Total Kjeldahl nitrogen in soil/plant. QuickChem method 13-107-06-2-3. Lachat Instruments, Loveland, CO.

Landry, J., S. Delhaye, and C. Damerval. 2000. Improved method for isolating and quantitating $\alpha$-amino nitrogen as nonprotein, true protein, salt-soluble proteins, zeins, and true glutelins in maize endosperm. Cereal Chem. 77:620-626.

Landry, J., S. Delhaye, and C. Damerval. 2002. Comparative efficiencies of isopropyl and tert-butyl alcohols for extracting zeins from maize endosperm. J. Agric. Food Chem. 50:4131-4134. .

Lanzas, C., D. G. Fox, and A. N. Pell. 2007. Digestion kinetics of dried cereal grains. Anim. Feed Sci. Technol. 136:265-280.

Larson, J., and P. C. Hoffman. 2008. Technical note: A method to quantify prolamin proteins in corn that are negatively related to starch digestibility in ruminants. J. Dairy Sci. 91:4834-4839.

Leibovich, J., J. T. Vasconcelos, and M. L. Galyean. 2009. Effects of corn processing method in diets containing sorghum wet distillers grain plus solubles on performance and carcass characteristics of finishing beef cattle and on in vitro fermentation of diets. J. Anim. Sci. 87:2124-2132.

Littell, R. C., R. J. Freund, and P. C. Spector. 1993. SAS System for Linear Models. 3rd ed. SAS Inst. Inc., Cary, NC.

Lopes, J. C., R. D. Shaver, P. C. Hoffman, M. S. Akins, S. J. Bertics, H. Gencoglu, and J. G. Coors. 2009. Type of corn endosperm influences nutrient digestibility in lactating dairy cows. J. Dairy Sci. 92:4541-4548

Masoero, F., A. Gallo, C. Zanfi, G. Giuberti, and M. Spanghero. 2011. Effect of nitrogen fertilization on chemical composition and rumen fermentation of different parts of plants of three corn hybrids. Anim. Feed Sci. Technol. 164:207-216.

Parissi, Z. M., T. G. Papachristou, and A. S. Nastis. 2005. Effect of drying method on estimated value of browse species using and in vitro gas production technique. Anim. Feed Sci. Technol. 123124:119-128.

SAS Institute. 2001. SAS User's Guide: Statistics. SAS Inst. Inc., Cary, NC 